\title{
A new genus and species of the Monticelliinae (Eucestoda: Proteocephalidea), a parasite of Pseudoplatystoma fasciatum (Pisces: Siluriformes) from the Paraná River basin (Argentina), with comments on microtriches of proteocephalideans
}

\author{
Nathalia J. Arredondo ${ }^{1}$, Alain de Chambrier ${ }^{2}$ and Alicia A. Gil de Pertierra \\ ${ }^{1}$ Laboratorio de Helmintología, Departamento de Biodiversidad y Biología Experimental, Facultad de Ciencias \\ Exactas y Naturales, Ciudad Universitaria, Universidad de Buenos Aires, Buenos Aires, Argentina; \\ ${ }^{2}$ Department of Invertebrates, Natural History Museum, Geneva, Switzerland
}

\begin{abstract}
This paper describes Regoella brevis gen. n. et. sp. n. (Proteocephalidea: Monticelliinae), a parasite of the intestine of the barred sorubim Pseudoplatystoma fasciatum (Linnaeus) from the Paraná River basin. The new genus is placed in the Monticelliinae because of the cortical position of the genital organs. It differs from all known genera included in the Monticelliinae by the following combination of characters: 1) a quadrangular scolex with a truncated conical apex and formed by four lobes separated by grooves; 2) uniloculate suckers of inverted triangular shape possessing a small cone-shaped projection at each corner of the anterior margin; 3) strobila consisting of a low number of proglottides; 4) testes arranged in one dorsal field; 5) a cirrus-sac, which represents more than one half of the proglottis width, cirrus surrounded by conspicuous chromophilic gland cells; 6) a butterfly-shaped and strongly lobulate ovary; and 7) formation of uterus of type 2. The examination of the tegument surface with scanning electron microscopy revealed the occurrence of three types of microtriches: acicular and capilliform filitriches and gladiate spinitriches. The new species is the eighth proteocephalidean reported from P. fasciatum, six of which are commonly found in the Amazon and Paraná River basins.
\end{abstract}

Keywords: Cestoda, Proteocephalidea, taxonomy, morphology, barred sorubim, Pimelodidae, South America

The Pimelodidae, which includes large catfishes (Froese and Pauly 2012), is the most diversified family of siluriforms inhabiting the great river basins of South America. Large catfishes of the genera Brachyplatystoma Bleeker, Pseudoplatystoma Bleeker and Zungaro Bleeker are mainly parasitized by a rich fauna of proteocephalidean cestodes (de Chambrier and Vaucher 1999, Rego et al. 1999, Carfora et al. 2003, de Chambrier et al. 2006a).

During a collecting trip in the Paraná River basin in Argentina, specimens of an undescribed proteocephalidean tapeworm were collected from the intestines of the barred sorubim, Pseudoplatystoma fasciatum (Linnaeus), locally known as 'surubí atigrado'. These tapeworms were assigned to the Monticelliinae Mola, 1929, but could not be allocated to any of the known genera. Therefore, a new genus is proposed to accommodate the new species described herein, which is the eighth proteocephalidean species found in P. fasciatum.

\section{MATERIALS AND METHODS}

Ten specimens of Pseudoplatystoma fasciatum (Siluriformes: Pimelodidae) were caught during December 2001, 2003 and
2010 in the Colastiné River (tributary of the Paraná River), Santa Fe Province, Argentina. All tapeworms found in the intestines were removed, fixed in hot $4 \%$ formaldehyde solution and subsequently stored in $70 \%$ ethanol. Additionally, small pieces of strobila from the new worms were placed in $99 \%$ pure ethanol for future DNA analysis and deposited at the Natural History Museum, Geneva, Switzerland (MHNG-PLAT 79184) and at the Laboratory of Helminthology, Facultad de Ciencias Exactas y Naturales, Universidad de Buenos Aires, Argentina. Entire tapeworms were stained with Langeron's alcoholic hydrochloric carmine (Langeron 1949), differentiated in acid ethanol, dehydrated through a graded ethanol series, cleared in beechwood creosote and mounted in Canada balsam. Details of the internal anatomy were determined from thick, hand-cut, transverse serial sections of proglottides stained with Langeron's alcoholic hydrochloric carmine. Intrauterine eggs were examined in distilled water for drawing. Type material is deposited in the Parasitological Collection of the Museo Argentino de Ciencias Naturales 'Bernardino Rivadavia', Buenos Aires, Argentina (MACN-Pa); the Natural History Museum, Geneva, Switzerland (MHNG-PLAT); and the Institute of Parasitology, České Budějovice, Czech Republic (IPCAS).

Three entire specimens of the new species were prepared for scanning electron microscopy (SEM) as follows: worms were

Address for correspondence: A.A. Gil de Pertierra, Laboratorio de Helmintología, Departamento de Biodiversidad y Biología Experimental, Facultad de Ciencias Exactas y Naturales, Ciudad Universitaria, Int. Güiraldes 2160, Pabellón II, 4 Piso, Universidad de Buenos Aires, C1428EGA, Buenos Aires, Argentina. Phone: +54 11 4576-3349; Fax: +54 11 4576-3384; E-mail: helminto@bg.fcen.uba.ar 
Table 1. Microthrix pattern of Regoella brevis gen. n. et sp. n. from Pseudoplatystoma fasciatum (for explanation of abbreviations see Materials and Methods).

\begin{tabular}{lllc}
\hline Surfaces & Microthrix type & Size & Fig. 3 \\
\hline ASS & AF & $0.45-0.58(0.47) \times 0.08-0.11(0.09 ; \mathrm{n}=11)$ & $\mathrm{D}$ \\
MSS & GS $/$ CF & $0.60-0.85(0.73) \times 0.30-0.50(0.36 ; \mathrm{n}=6) / 0.68-1.50(1.10) \times 0.10-0.16(0.12 ; \mathrm{n}=6)$ & $\mathrm{E}$ \\
LSS & GS $/$ CF & $0.90-1.07(0.98) \times 0.30-0.45(0.37 ; \mathrm{n}=6) / 1.10-1.80(1.35) \times 0.10-0.13(0.11 ; \mathrm{n}=6)$ & $\mathrm{F}$ \\
N-ASS & GS $/$ CF & $1.90-2.36(2.13) \times 0.48-0.56(0.51 ; \mathrm{n}=4) / 1.52-1.95(1.71) \times 0.10-0.13(0.12 ; \mathrm{n}=3)$ & G \\
PZS & GS & $3.72-4.70(4.15) \times 1.00-1.30(1.15 ; \mathrm{n}=4)$ & $\mathrm{H}$ \\
IPS & GS & $4.60-5.50(5.10) \times 1.26-1.35(1.31 ; \mathrm{n}=3)$ & $\mathrm{I}$ \\
MPS (anterior) & GS & $5.95-6.62(6.30) \times 1.50-1.75(1.64 ; \mathrm{n}=3)$ & $\mathrm{J}$ \\
MPS (posterior) & GS (large) / GS (smaller) / AF* & $4.15-5.93(5.10) \times 1.26-1.62(1.40 ; \mathrm{n}=5) / 2.93-3.10 \times 0.83-1.12(\mathrm{n}=2)$ & $\mathrm{K}$ \\
\hline
\end{tabular}

*not measured.

post-fixed in $1 \%$ osmium tetroxide, dehydrated through a graded ethanol series, dried with hexamethyldisilazane (Riedel-De Haën $\left.{ }^{\circledR}\right)$, mounted on stubs with adhesive tape, sputter coated with gold in a Thermo VG Scientific Polaron SC 7620 and examined with a Philips XL 30 scanning electron microscope. The type and distribution pattern of microtriches were studied on the scolex, proliferation zone (neck), and immature, mature and gravid proglottides. Measurements of the microtriches were taken from photomicrographs. Terminology used for description of microtriches follows Chervy (2009). Unless otherwise stated, all measurements are given in micrometres, with the range followed in parentheses by the mean and number of observations (n). For two-dimensional measurements, length is given before width. Illustrations were made with the aid of a camera lucida attached to Zeiss Axioscope and Leica DMLB microscopes equipped with differential interference contrast optics. Abbreviations used, including Table 1, are: ASS - apical surface of the scolex; MSS - marginal surface of suckers; LSS - luminal surface of suckers; N-ASS - non-adherent surface of suckers; PZS - proliferation zone surface; IPS - immature proglottis surface; MPS - mature proglottis surface; AF - acicular filitriches; GS - gladiate spinitriches; $\mathrm{CF}$ - capilliform filitriches.

\section{RESULTS}

Regoella gen. $\mathrm{n}$.

Proteocephalidea, Proteocephalidae, Monticelliinae. Testes, ovary, vitelline follicles and uterus cortical. Smallsized worms, flattened dorsoventrally. Strobila acraspedote, consisting of a low number of elongate mature and gravid proglottides. Scolex quadrangular, apex truncated conical. Metascolex absent. Suckers uniloculate, inverted triangle-shaped, with small cone-shaped projection at each corner of anterior margin. Proliferation zone (neck) present. Testes cortical, arranged in one dorsal field. Genital pore usually equatorial, irregularly alternating. Ovary cortical, situated posteriorly, butterfly-shaped. Vagina usually posterior to cirrus-sac, with muscular vaginal sphincter. Vitelline follicles cortical, arranged in two lateral bands. Uterine stem and uterine branches cortical. Formation of uterus of type 2 (sensu de Chambrier et al. 2004a). Parasites of Neotropical siluriform fishes (Pimelodidae).

Type and only species: Regoella brevis sp. n.

E ty mology: The generic name is given in honour of Amil- car A. Rego for his contribution to the systematics of proteocephalidean cestodes; the name should be treated as feminine.

Differential diagnosis. The new genus is placed in the Monticelliinae Mola, 1929, because it possesses testes, ovary, vitelline follicles and uterus in the cortex of the proglottis (Schmidt 1986, Rego 1994). The subfamily currently includes eight genera parasitizing freshwater fishes, Ageneiella de Chambrier et Vaucher, 1999; Chambriella Rego, Chubb et Pavanelli, 1999; Choanoscolex La Rue, 1911; Goezeella Fuhrmann, 1916; Lenhataenia de Chambrier et Scholz, 2008; Manaosia Woodland, 1935; Monticellia La Rue, 1911; and Spatulifer Woodland, 1934 (Rego 1994, de Chambrier and Vaucher 1999, Rego et al. 1999, de Chambrier 2003, de Chambrier and Scholz 2008).

Regoella gen. n. can be distinguished from the other genera of the Monticelliinae by the morphology of the scolex, which is unique in the subfamily in possessing uniloculate suckers forming an inverted triangle with a small cone-shaped projection at each corner of the anterior margin. Additionally to the morphology of the scolex, the new species is characterized by the following combination of characters: small-size worms, strobila consisting of a low number of elongated mature and gravid proglottides, internal longitudinal musculature weakly developed, represented by scarce bundles of muscle fibres, ovary butterfly-shaped, and uterus development of type 2 .

The new genus, can be differentiated from the individual genera of the Monticelliinae as follows: the suckers of Ageneiella, Chambriella, Goezeella and Lenhataenia are biloculate, whereas they are uniloculate in Choanoscolex, Manaosia, Monticellia and Spatulifer, similarly to those of the new genus. However, the suckers of Manaosia have horseshoe-shaped musculature around their distal margin (de Chambrier 2003), whereas they are rounded or elongate (oval) in Choanoscolex, Monticellia and Spatulifer, but tapered at the posterior margins in Choanoscolex and with a conspicuous metascolex in Spatulifer.

\section{Regoella brevis sp. $\mathrm{n}$.}

Figs. 1-3, Table 1

Description (based on 15 tapeworms and pieces of strobila as transverse sections; measurements made on nine specimens): Proteocephalidae, Monticelliinae. 
Small-sized worms, 7-16 mm $(10 ; \mathrm{n}=9)$ in total length. Strobila acraspedote, flattened dorsoventrally, anapolytic, consisting of 9-41 $(19 ; \mathrm{n}=9)$ immature proglottides (up to appearance of spermatozoa in vas deferens), 3-5 (4; $\mathrm{n}=9$ ) mature proglottides (up to appearance of eggs in uterus), 1-11 (4; $\mathrm{n}=9$ ) gravid proglottides (Fig. 1).

Immature proglottides wider than long, quadrangular or longer than wide 50-530 (220) $\times$ 120-300 (205) $(\mathrm{n}=28)$. Mature proglottides longer than wide 475-830 $(625) \times 215-380(280)(\mathrm{n}=17)$. Gravid proglottides longer than wide 700-1400 (880) × 240-440 (340) $(n=14)$ (Figs. 1, 2C,D).

Scolex small, quadrangular, formed by four lobes separated by grooves in apical view, wider than proliferation zone, 145-220 (170) × 125-190 (150) $(\mathrm{n}=8)$. Apex truncated, conical, without apical organ, with elongate, bottle-shaped gland-cells. Metascolex absent. Suckers uniloculate, inverted triangle-shaped with small cone-shaped projection at each corner of anterior margin, 95-150 $(115) \times 50-100(70)(\mathrm{n}=12)$. Proliferation zone (neck) 425-830 (560) × 70-135 (110) $(\mathrm{n}=8)$ (Figs. 1, 2A, $3 \mathrm{~A}-\mathrm{C})$.

Internal longitudinal musculature weakly developed, represented by scarce bundles of muscle fibres surrounding reduced medulla (Fig. 2E,F). Osmoregulatory canals usually situated between testes and vitelline follicles in anterior and middle part of proglottis, often overlapped by testes and ovary in dorsal view (Fig. 2C). Ventral canals 4-8 in diameter; dorsal canals 2-3 (Fig. 2B-F).

Testes cortical, oval to spherical 40-75 (50) $\times 25-50$ (40) $(\mathrm{n}=10) ; 28-49(35)(\mathrm{n}=13)$ in total number per mature proglottis, arranged in one field on dorsal side of proglottis, distributed in one or two irregular layers, separated only by vaginal canal, vas deferens and cirrus-sac, usually not surpassing osmoregulatory canals and not overlapping cirrus-sac and ovary (Fig. 2C-E).

Cirrus-sac pyriform, thick-walled, 100-180 (135) $\times$ $60-110(85)(n=17)$, occupying 43-60\% (48\%) $(n=17)$ of proglottis width in mature proglottides representing more than one half of the proglottis width. Cirrus long, occupies $42-66 \%(55 \%)(\mathrm{n}=15)$ of cirrus-sac length, surrounded by conspicuous chromophilic gland cells. Vas deferens coiled, located anterior to cirrus-sac, 30-60 in diameter, usually surpassing body mid-line in mature and gravid proglottides. Genital pores irregularly alternating, $33-55 \%(44 \%)(n=17)$ from anterior margin of mature proglottis (Figs. 1, 2B-D).

Ovary cortical, butterfly-shaped, strongly lobulate, $120-240(165) \times 125-235(175)(\mathrm{n}=17)$, occupying $56-75 \%(62 \%)(n=17)$ of mature proglottis width. Ovary expands to anterior part of gravid proglottides, occupying $22-40 \%(27 \%)(n=17)$ of proglottis length (Fig. 2C,D,F). Relative size of ovary surface to proglottis surface (sensu de Chambrier et al. 2012) 10-12\%. Vagina thin-walled, usually posterior to cirrus-sac (98\%), 8-10 wide in its ascending portion, with conspicuous subterminal sphincter
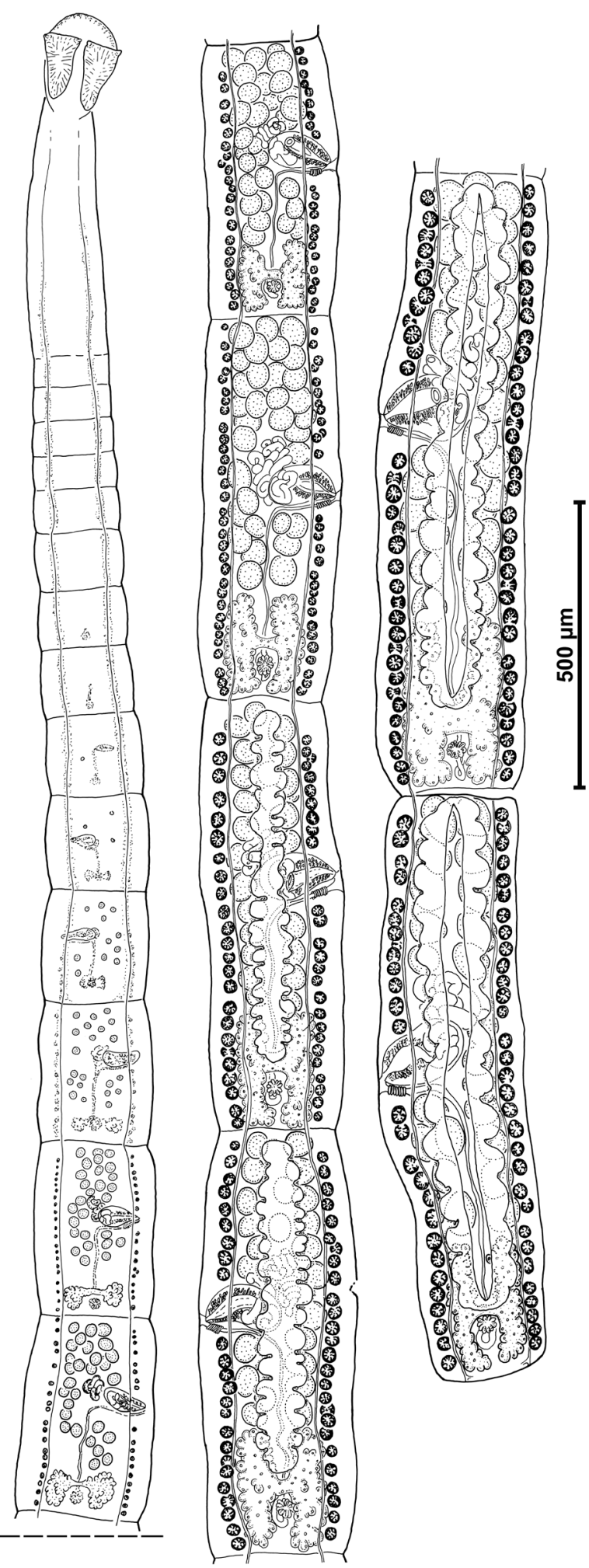

Fig. 1. Regoella brevis gen. n. et sp. n. from Pseudoplatystoma fasciatum. Entire worm, dash line indicate portions of strobila not shown in figure; ventral view, holotype (MACN-Pa 545/1).

45-90 (70) $(\mathrm{n}=8)$ long (Figs. 1, 2B-D). Vitelline follicles cortical, arranged in two lateral bands often crescentshaped in transverse sections, extend $97-99 \%$ of total 
A

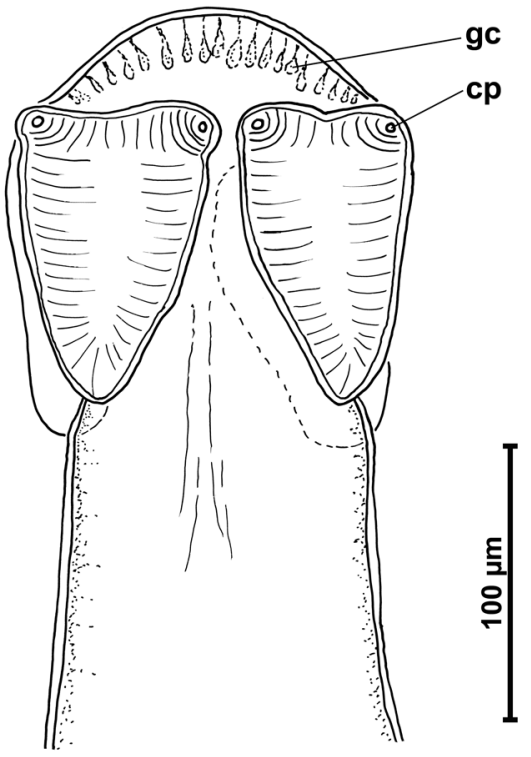

B

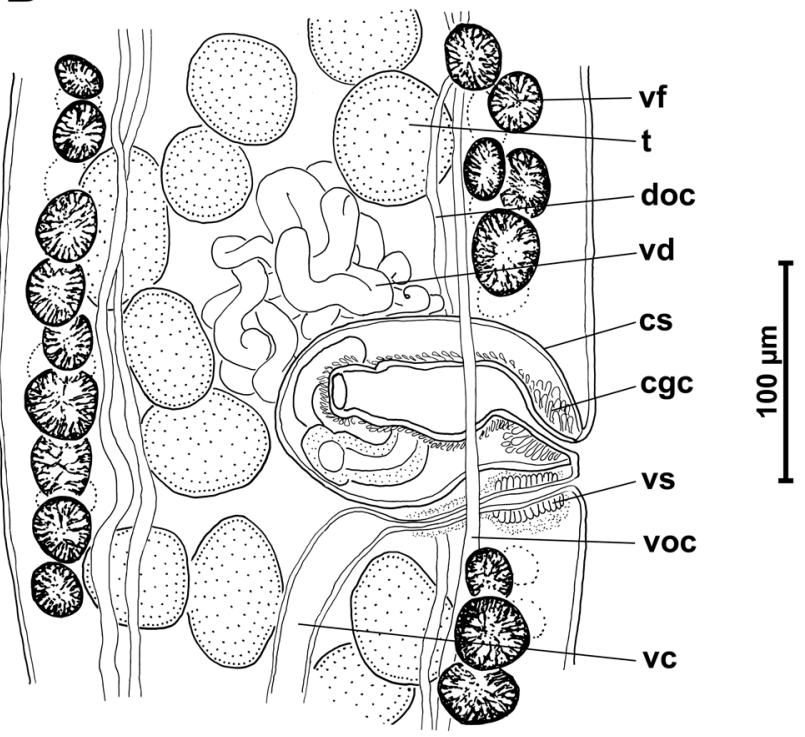

C

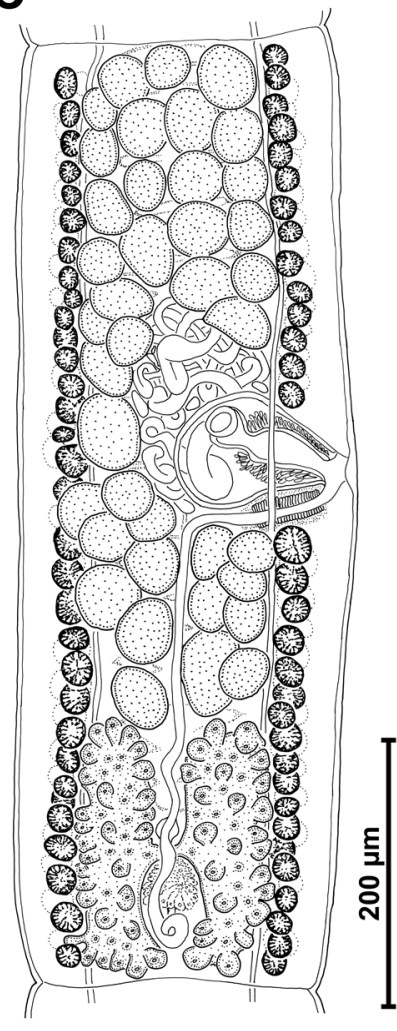

D

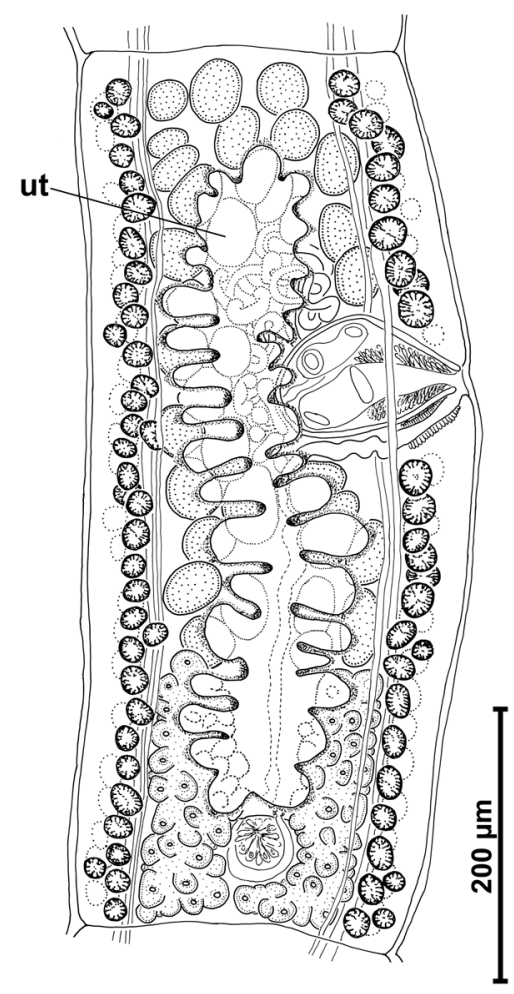

$\mathbf{E}$
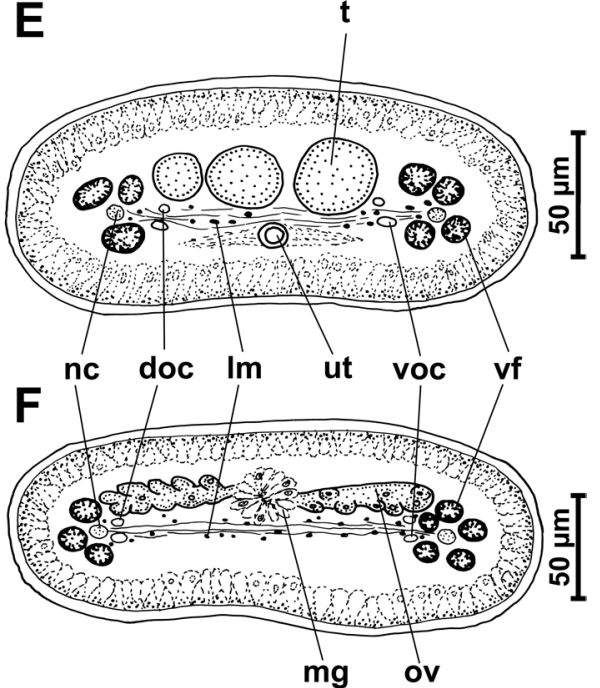

G

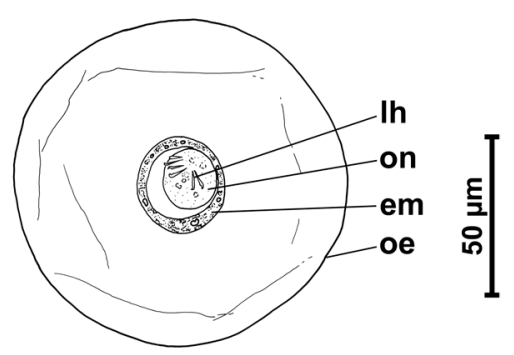

Fig. 2. Regoella brevis gen. n. et sp. n. from Pseudoplatystoma fasciatum. A - scolex; dorsoventral view, paratype (MACN-Pa 545/4); B - detail of terminal genitalia; ventral view, uterus not figured, paratype (MHNG-PLAT 82482; C - mature proglottis; dorsal view, holotype (MACN-Pa 545/1); D - gravid proglottis; ventral view, paratype (MACN-Pa 545/5); E - transverse section at level of testes, paratype (MACN-Pa 545/2); $\mathbf{F}$ - transverse section at level of ovary, paratype (MACN-Pa 545/2); G - egg. $A b-$ breviations: cgc - cirrus gland cells; cp - cone-shaped projection; cs - cirrus-sac; doc - dorsal osmoregulatory canal; em - embryophore; gc - gland cells; lh - larval hooks; lm - longitudinal musculature; mg - Mehlis' gland; nc - nerve cord; oe - outer envelope; on - oncosphere; ov - ovary; $\mathrm{t}$ - testis; ut - uterus; vc - vaginal canal; vd - vas deferens; vf - vitelline follicles; voc - ventral omoregulatory canal; vs - vaginal sphincter. 

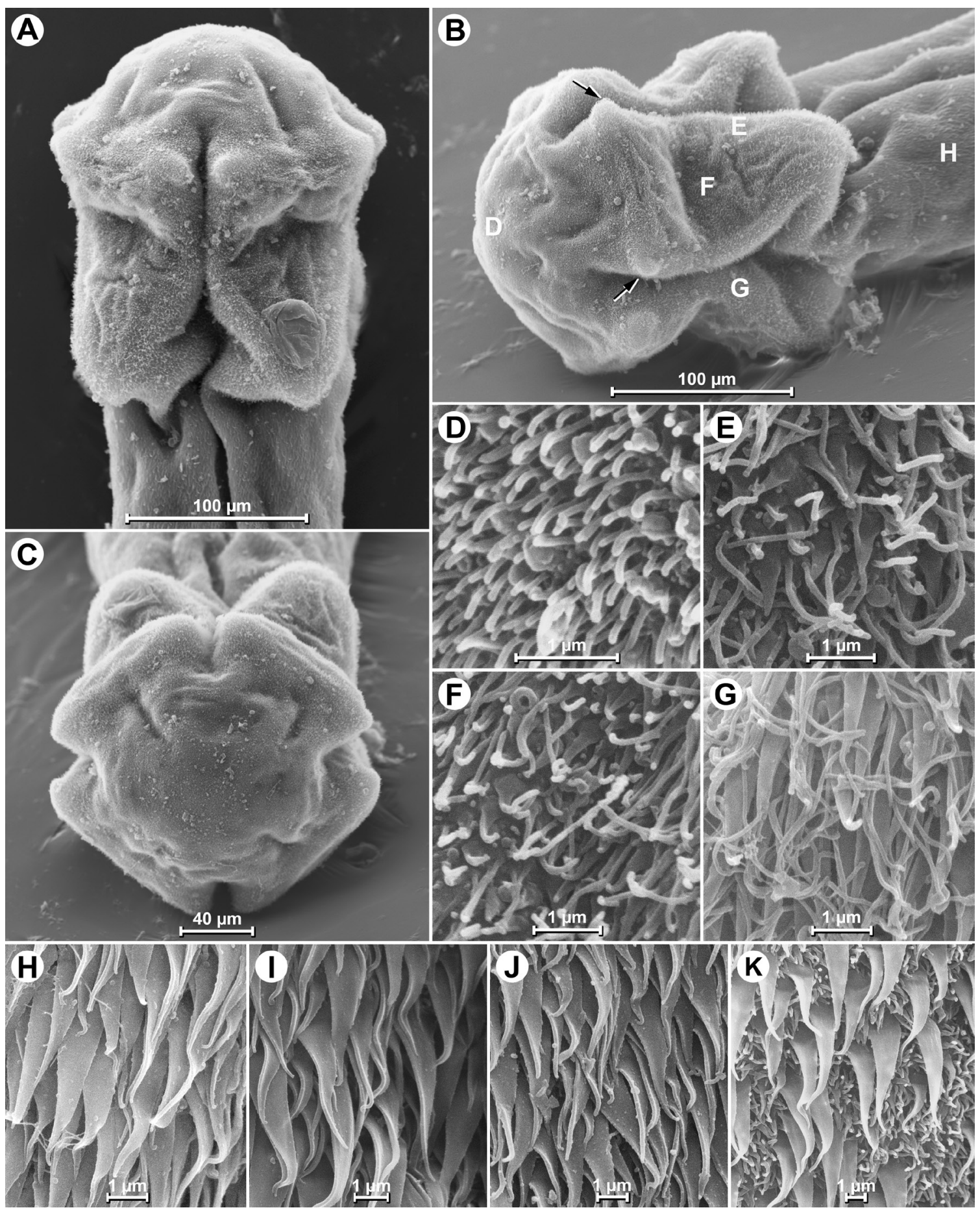

Fig. 3. Regoella brevis gen. n. et sp. n. from Pseudoplatystoma fasciatum, scanning electron micrographs. A - scolex, dorsoventral view; B - scolex, lateral view, black arrows show cone-shaped projections; letters D-H indicate surfaces shown at higher magnification in Fig. 3D-H; C - scolex, apical view; D - apical surface of scolex: $\mathbf{E}$ - marginal surface of suckers: $\mathbf{F}$ - luminal surface of suckers; $\mathbf{G}$ - non-adherent surface of suckers; $\mathbf{H}$ - proliferation zone surface; I - immature proglottis surface; $\mathbf{J}$ - surface of anterior part of mature proglottis; $\mathbf{H}$ - surface of posterior part of mature proglottis.

proglottis length. Follicles not overlapping vagina and cirrus-sac (Fig. 2B-F).

Uterine stem in ventral cortex; uterine development of type 2 (sensu de Chambrier et al. 2004a). Uterine branch- es run in ventral cortex, occupying $35-60 \%(49 \%)(\mathrm{n}=9)$ of gravid proglottis width. Aporal uterine branches 17-20 $(18)(n=4)$ in number, poral uterine branches 14-19 (15) $(n=4)$ in number (Fig. 2D,E). Intrauterine eggs spherical; 
hyaline outer envelope $85-110(100)(\mathrm{n}=7)$ in diameter; embryophore 25-30 (28) $(\mathrm{n}=7)$ in diameter, consisting of two layers (outer one transparent, inner one containing nuclei); oncosphere slightly oval 15-25 (19) × 15-20 (18) $(\mathrm{n}=7)$; embryonic hooks 6-8 long $(\mathrm{n}=6)$ (Fig. 2G).

Type host: Pseudoplatystoma fasciatum (Linnaeus) (Siluriformes: Pimelodidae); common names in Argentina 'surubí atigrado', 'cachorro (juvenile)'; 'cachara', 'surubim' in Brazil; 'doncella' in Perú; 'barred sorubim' in English.

Type locality: Colastiné River (tributary of Paraná River) $\left(31^{\circ} 40^{\prime} \mathrm{S}, 60^{\circ} 46^{\prime} \mathrm{W}\right)$, near Barrio Colastiné Sur, Santa Fe Province, Argentina.

Site of infection: Anterior part of intestine.

Infection rate: Prevalence 40\% (4/10); intensity 1-174 worms, mean intensity 45, abundance 18 .

Type material: Holotype MACN-Pa No. 545/1 (entire worm and transverse sections, on one slide), paratypes MACN-Pa No. 545/2-5 (four entire worms, two of them with transverse sections, each one on one slide); paratypes (MHNG-PLAT 79184 (entire worm and transverse sections, on one slide, piece of strobila from this tapeworm placed in $99 \%$ pure ethanol), MHNG-PLAT 82480, MHNG-PLAT 82481, MHNG-PLAT 82482 (three entire worms, two of them with transverse sections, each one on one slide); paratypes IPCAS C-633/1-4 (four entire worms, two of them with transverse sections, each one on one slide).

E t y m o logy: From the Latin 'brevis' meaning 'small'; feminine in gender.

\section{Microthrix pattern}

Surface of scolex, proliferation zone and proglottides covered with acicular and capilliform filitriches and gladiate spinitriches. Acicular filitriches cover ASS (Fig. 3D), being interspersed with gladiate spinitriches on posterior surface of MPS (Fig. 3K). Gladiate spinitriches interspersed with capilliform filitriches on the MSS, LSS and N-ASS (Fig. 3E-G), being only microthrix type on PZS, IPS and anterior surface of MPS (Fig. 3H-J). Gladiate spinitriches on posterior surface of MPS of two different sizes (Fig. 3K, Table 1). Microtriches of gravid proglottis not shown of same microthrix pattern as mature proglottides.

\section{DISCUSSION}

Regoella brevis gen. $\mathrm{n}$. et sp. $\mathrm{n}$. belongs to the Monticelliinae based on the cortical position of the testes, ovary, vitelline follicles and uterus, as defined by Schmidt (1986) and Rego (1994). The new species is allocated to a new genus due to the unique morphological features of its scolex, which has a quadrangular and conical apex, and four uniloculate inverted triangle-shaped suckers with a small cone-shaped projection at each corner of the anterior margin.

The cirrus of $R$. brevis is surrounded by conspicuous chromophilic unicellular glands. Very similar unicellular glands were described in Proteocephalus sophiae de
Chambrier et Rego, 1994 (Proteocephalinae) (de Chambrier and Rego 1994); these gland cells have also been observed for example in, Electrotaenia malopteruri (Fritsch, 1886) (Gangesiinae) and Sandonella sandoni (Lynsdale, 1960) (Sandonellinae) by de Chambrier et al. (2004b, 2008). They were illustrated, but not described, in Monticellia ophisterni Scholz, de Chambrier et Salgado-Maldonado, 2001 and Monticellia amazonica de Chambrier et Vaucher, 1997 (both Monticelliinae) (see Fig. 6 in Scholz et al. 2001 and Fig. 7 in Scholz et al. 2008, respectively).

Ammann and de Chambrier (2008) and de Chambrier et al. (2012) were the first to propose that the relative ovarian size is a potentially useful character to differentiate species of speciose genera Proteocephalus Weinland, 1858 from fishes and Ophiotaenia La Rue, 1911 (both Proteocephalinae) from reptiles. The relative ovarian size of $R$. brevis (10-12\%) falls into the range reported for Proteocephalus spp. (see Table 2 in de Chambrier et al. 2012).

The relative ovarian size was calculated for other proteocephalidean genera from fish that have good-quality illustrations, such as: Harriscolex kaparari (Woodland, 1935) (19\%), H. nathaliae Gil de Pertierra et de Chambrier, 2013 (both Zygobothriinae) (16\%), Monticellia santafesina Arredondo et Gil de Pertierra, 2010 (23\%) and Spatulifer maringaensis Pavanelli et Rego, 1989 (both Monticelliinae) (18\%). These values also fall into the range of Proteocephalus species from fishes (5.4-28.8\%, see de Chambrier et al. 2012), but it should be pointed out that the range for the latter species is particularly wide.

Nevertheless, it seems that the relative ovarian size of species of Proteocephalus and some species of other genera, which parasitize fishes, are higher than those for Ophiotaenia species from reptiles. An exception represents Margaritaella gracilis Arredondo et Gil de Pertierra, 2012 (Proteocephalinae) described from Callichthys callichthys (Linnaeus) (see Arredondo and Gil de Pertierra 2012), whose relative ovarian size is very small $(0.6-1.8 \%)$, even smaller than that of Ophiotaenia species from reptiles (see Table 2 in Ammann and de Chambrier 2008).

The study of the tegumental surface of $R$. brevis revealed the presence of acicular and capilliform filitriches and gladiate spinitriches distributed on the scolex, proliferation zone and proglottides. The gladiate spinitriches are the most common microthrix type, increase in size from the N-ASS to the anterior MPS and decrease in size and density along the tegument of the posterior MPS (Table 1).

Studies characterizing the microtriches of proteocephalidean cestodes are scarce and results obtained so far suggest a low degree of type variability compared to other groups of cestodes, especially parasites of elasmobranchs (Chervy 2009). The following microthrix types have been recorded on the tegument surface of proteocephalideans 
cestodes: acicular, capilliform and papilliform filitriches, and coniform and gladiate spinitriches. These three type of filitriches and gladiate spinitriches are the only microthrix type covering the ASS in most species (e.g. Gil de Pertierra 2005, 2009, de Chambrier 2006, de Chambrier et al. 2006b, Arredondo and Gil de Pertierra 2008, 2012) and in R. brevis (Fig. 3D), except for Ritacestus ritaii (Verma, 1926) (Gangesiinae), which possesses coniform spinitriches interspersed with capilliform filitriches on the ASS (de Chambrier et al. 2011a). The ASS of Nomimoscolex lopesi Rego, 1989 (Zygobothriinae) was erroneously described by Gil de Pertierra (2005); its surface is in fact covered by acicular filitriches interspersed with capilliform filitriches instead of blade-like spiniform as originally reported (see Fig. 4C in Gil de Pertierra 2005).

The gladiate spinithrix is the most frequent microthrix type in proteocephalidean cestodes, occurring on the surface of the scolex and strobila. The gladiate spinitriches may be either alone or interspersed with filitriches, as in Margaritaella gracilis Arredondo et Gil de Pertierra, 2012; Monticellia magna (Rego, dos Santos et Silva, 1974) (Monticelliinae); Pangasiocestus romani Scholz et de Chambrier, 2012 (Gangesiinae); Scholzia emarginata (Diesing, 1850) (Proteocephalinae); Spatulifer rugosa (Woodland, 1935) (Monticelliinae) (see Gil de Pertierra 2004, de Chambrier et al. 2005, Arredondo and Gil de Pertierra 2008, 2012, Scholz and de Chambrier 2012); and also in the new species described herein (Fig. 3E-K).

Coniform spinitriches are rare among protocephalidean cestodes and have been reported on the tegument of Kapsulotaenia sandgroundi (Carter, 1943) (Acanthotaeniinae), R. ritaii and Vermaia pseudotropii (Verma, 1829) (both Gangesiinae), parasitizing freshwater fishes from Asia and belonging to the most basal groups of proteocephalideans (de Chambrier 2006, Ash et al. 2010, de Chambrier et al. 2011a). Likewise, papilliform filitriches have only been recorded in Corallobothrium solidum Fritsch, 1886 (Corallobothriinae); Luciaella ivanovae Gil de Pertierra, 2009 (Peltidocotylinae); Proteocephalus synodontis Woodland, 1925 (Proteocephalinae) and S. emarginata (Diesing, 1850) from Africa and South America (de Chambrier et al. 2005, 2011b, Gil de Pertierra 2009, Scholz et al. 2011).

It is interesting to note that the onchobothriid cestodes of the genus Acanthobothrium van Beneden, 1849, which are considered the sister group of the Proteocephalidea (Waeschenbach et al. 2007, 2012, Olson et al. 2008, Healy et al. 2009) share the same types of microtriches. For example, the scolices of the species of Acanthobothrium described by Fyler and Caira (2006), Twohig et al. (2008) and Fyler et al. (2009) are covered with papilliform and capilliform filitriches and gladiate spinitriches. Thus, the types of microtriches and their distribution on the tegu- ment surface provided additional evidence concerning the relationship between these taxa.

Among proteocephalidean cestodes of fish, seven species have been characterized as having cone-shaped projections (papilla-like) at each corner of the anterior sucker margin; these are Euzetiella tetraphylliformis de Chambrier, Rego et Vaucher, 1999 (Proteocephalinae); Harriscolex kaparari (Woodland, 1935); H. nathaliae Gil de Pertierra et de Chambrier 2013; Houssayela sudobim (Woodland, 1935); Nomimoscolex lenha (Woodland, 1933) (all Zygobothriinae); Proteocephalus piramutab (Woodland, 1933); and P. sophiae (both Proteocephalinae) (see Woodland 1933, Rego 1987, de Chambrier and Rego 1994, de Chambrier et al. 1999, de Chambrier and Scholz 2005, 2008, Gil de Pertierra and de Chambrier 2013). The taxonomic status of the latter three species of proteocephalidean cestodes should be re-evaluated based on new material because species of Nomimoscolex and Proteocephalus have simple round to oval suckers (Schmidt 1986, Rego 1994). The new genus described here is the eighth representative of the Proteocephalidea showing a cone-shaped projection at each corner of the anterior margin of the suckers (Figs. 2A, 3B), but the only member of the Monticelliinae that possesses this characteristic.

Pseudoplatystoma fasciatum inhabits the Amazon and Paraná basins and is now parasitized by eight proteocephalidean species, six of which are commonly found in both basins. These are Choanoscolex abscissus Riggenbach, 1895; Monticellia spinulifera Woodland, 1934; Nomimoscolex lopesi Rego, 1990; Nomimoscolex sudobim Woodland, 1935; Peltidocotyle rugosa Diesing, 1850 and Spatulifer rugosa (Woodland, 1935). Up to date, Houssayela sudobim and Regoella brevis were recorded in the Amazon and Paraná rivers, respectively, but is interesting to note that the former species has a low prevalence and intensity of infection. It was described for the first time by Woodland (1935) and redescribed after 70 years in the Peruvian Amazon River (Woodland 1935, de Chambrier and Scholz 2005). Regoella brevis shows a relative high prevalence and intensity of infection, but because it is a small worm, it cannot be excluded that it may have been previously considered to be an immature form of other proteocephalidean species.

Acknowledgements. A.A.G. de P. thanks Jean Mariaux for his invitation to the Museum d'Histoire Naturelle, Geneva, Switzerland, and for financial support. The authors are indebted to Roman Kuchta for his helpful suggestions on a draft version of the manuscript. Special thanks are due to the two reviewers for their valuable comments that help improve this manuscript. This research was also supported by the Universidad de Buenos Aires, Argentina (Grant UBACyT 20020110100199) and in part by the National Science Foundation PBI awards Nos. 0818696 and 0818823 . 
Ammann M., De Chambrier A. 2008: Ophiotaenia gilberti sp. n. (Eucestoda: Proteocephalidea), a parasite of Thamnodynastes pallidus (Serpentes: Colubridae) from Paraguay. Rev. Suisse Zool. 115: 541-551.

Arredondo N.J., Gil de Pertierra A.A. 2008: The taxonomic status of Spatulifer cf. maringaensis Pavanelli \& Rego, 1989 (Eucestoda: Proteocephalidea) from Sorubim lima (Bloch \& Schneider) (Pisces: Siluriformes), and the use of the microthrix pattern in the discrimination of Spatulifer spp. Syst. Parasitol. 70: $223-236$.

Arredondo N.J., Gil de Pertierra A.A. 2012: Margaritaella gracilis gen. n. et sp. n. (Eucestoda: Proteocephalidea), a parasite of Callichthys callichthys (Pisces: Siluriformes) from the Paraná River basin, Argentina. Folia Parasitol. 59: 99-102.

Ash A., de Chambrier A., Scholz T., Kar P.K. 2010: Redescription of Vermaia pseudotropii, a hyperapolytic freshwater tapeworm, and composition of Vermaia Nybelin, 1942 (Cestoda: Proteocephalidea). Rev. Suisse Zool. 117: 665-677.

Carfora M., de Chambrier A., Vaucher C. 2003: Le genre Amphoteromorphus (Cestoda: Proteocephalidea), parasite de poisons-chat d'Amérique tropicale: étude morphologique et approche biosystématique par électrophorèse des protéines. Rev. Suisse Zool. 110: 381-409.

de Chambrier A. 2003: Systematic status of Manaosia bracodemoca Woodland, 1935 and Paramonticellia itapuensis Pavanelli et Rego, 1991 (Eucestoda: Proteocephalidea), parasites of Sorubim lima (Siluriformes: Pimelodidae) from South America. Folia Parasitol. 50: 121-127.

De Chambrier A. 2006: Kapsulotaenia sandgroundi (Carter, 1943) (Eucestoda: Proteocephalidea: Acanthotaeniinae), a parasite of Varanus komodoensis (Varanoidea: Varanidae) from Indonesia. Syst. Parasitol. 63: 83-93.

de Chambrier A., Binh T.T., Scholz T. 2012: Ophiotaenia bungari n. sp. (Cestoda), a parasite of Bungarus fasciatus (Ophidia: Elapidae) from Vietnam, with comments on the ovary surface as a new diagnostic character in proteocephalidean tapeworms. Syst. Parasitol. 81: 39-50.

de Chambrier A., Mariaux J., Sène A., Mahmoud Z.N., Scholz T. 2008: Sandonella sandoni (Lynsdale, 1960), an enigmatic and morphologically unique cestode parasitic in the osteoglossiform fish Heterotis niloticus in Africa. J. Parasitol. 94: 202-211.

de Chambrier A., Rego A.A. 1994: Proteocephalus sophiae n. sp. (Cestoda: Proteocephalidae), a parasite of the siluroid fish Paulicea luetkeni (Pisces: Pimelodidae) from the Brazilian Amazon. Rev. Suisse Zool. 101: 361-368.

de Chambrier A., Rego A.A., Gil de Pertierra A.A. 2005: Redescription of two cestodes (Eucestoda: Proteocephalidea) parasitic in Phractocephalus hemioliopterus (Siluriformes) from the Amazon and erection of Scholzia gen. n. Rev. Suisse Zool. 112: 735-752.

de Chambrier A., Rego A.A., Vaucher C 1999: Euzetiella tetraphylliformis n. gen., n. sp. (Eucestoda: Proteocephalidae) parasite of the neotropical sweat-water fish Paulicea luetkeni (Siluriformes: Pimelodidae). Parasite 6: 43-47.

de Chambrier A., Scholz T. 2005: Redescription of Houssayela sudobim (Woodland, 1935) (Cestoda: Proteocephalidea), a parasite of Pseudoplatystoma fasciatum (Pisces: Siluriformes) from the River Amazon. Syst. Parasitol. 62: 161-169.

de Chambrier A., Scholz T. 2008: Tapeworms (Cestoda: Proteocephalidea) of firewood catfish Sorubimichthys planiceps
(Siluriformes: Pimelodidae) from the Amazon River. Folia Parasitol. 55: 17-28.

de Chambrier A., Scholz T., Ash A., Kar P.K. 2011a: Ritacestus gen. n. (Cestoda: Proteocephalidea) and redescription of $R$. ritaii comb. n., a parasite of Rita rita (Siluriformes) in India. Folia Parasitol. 58: 279-288.

De Chambrier A., Scholz T., Ibraheem M.H. 2004b: Redescription of Electrotaenia malopteruri (Fritsch, 1886) (Cestoda: Proteocephalidae), a parasite of Malapterurus electricus (Siluriformes: Malapteruridae) from Egypt. Syst. Parasitol. 57: 97-109.

de Chambrier A., Scholz T., Kuchta R., Posel P., Mortenthaler M., Chuquipiondo Guardia C. 2006a: Tapeworms (Cestoda: Proteocephalidea) of fishes from the Amazon River in Peru. Comp. Parasitol. 73: 111-120.

de Chambrier A., Scholz T., Mahmoud Z.N., Mariaux J., JIRKU゚ M. 2011b: Tapeworms (Cestoda: Proteocephalidea) of Synodontis spp. (Siluriformes) in Africa: survey of species and their redescriptions. Zootaxa 2976: 1-14.

de Chambrier A., Takemoto R.M., Pavanelli G.C. 2006b: Nomimoscolex pertierrae n. sp. (Eucestoda: Proteocephalidea), a parasite of Pseudoplatystoma corruscans (Siluriformes: Pimelodidae) in Brazil and redescription of N. sudobim Woodland, 1935, a parasite of P. fasciatum. Syst. Parasitol. 64: 191-202.

de Chambrier A., Vaucher C. 1999: Proteocephalidae et Monticelliidae (Eucestoda: Proteocephalidea) parasites de poissons d'eau douce au Paraguay, avec descriptions d'un genre nouveau et de dix espèces nouvelles. Rev. Suisse Zool. 106: 165-240.

de Chambrier A., Zehnder M.P., Vaucher, C., Mariaux J. 2004a: The evolution of the Proteocephalidea (Platyhelminthes, Eucestoda) based on an enlarged molecular phylogeny, with comments on their uterine development. Syst. Parasitol. 57: $159-171$.

Chervy L. 2009: Unified terminology for cestode microtriches: a proposal from the International Workshops on Cestode Systematics in 2002-2008. Folia Parasitol. 56: 199-230.

Froese R., Pauly D. (Eds.) 2012: FishBase. World Wide Web electronic publication. www.fishbase.org, version 12/2012.

Fyler C.A., Caira J.N. 2006: Five new species of Acanthobothrium (Tetraphyllidea: Oncobothriidae) from the freshwater stingray Himantura chaophraya (Batoidea: Dasyatidae) in Malaysian Borneo. J. Parasitol. 92: 105-125.

Fyler C.A., Caira J.N., Jensen K. 2009: Five new species of Acanthobothrium (Cestoda: Tetraphyllidea) from an unusual species of Himantura (Rajiformes: Dasyatidae) from northern Australia. Folia Parasitol. 56: 107-128.

Gil de Pertierra A.A. 2004: Redescription of Monticellia magna (Rego, dos Santos \& Silva, 1974) (Eucestoda: Monticelliidae) parasite of Pimelodus spp. (Pisces: Siluriformes) from Argentina, and morphological study of microtriches. Rev. Suisse Zool. 111: $11-20$.

Gil de Pertierra A.A. 2005: Comparative study of the microtriches of adult cestodes (Proteocephalidea: Monticelliinae), and some comment son their systematic value. Zool. Anz. 243: 295-304.

Gil de Pertierra A.A. 2009: Luciaella ivanovae n. gen., n. sp. (Eucestoda: Proteocephalidea: Peltidocotylinae), a parasite of Ageneiosus inermis (L.) (Siluriformes: Auchenipteridae) in Argentina. Syst. Parasitol. 73: 71-80. 
Gil de Pertierra A.A. de Chambrier A. 2013: Harriscolex nathaliae n. sp. (Cestoda: Proteocephalidea) from Pseudoplatystoma corruscans (Pisces: Siluriformes, Pimelodidae) in the Paraná River basin, Argentina. J. Parasitol. 99: in press.

Healy C.J., Caira J.N., Jensen K., Webster B.L., Littlewood D.T.J. 2009: Proposal for a new tapeworm order, Rhinebothriidea. Int. J. Parasitol. 39: 497-511.

Langeron M. 1949: Précis de Microscopie, 7th Edition. Masson et Cie, Paris, $1429 \mathrm{pp}$

Olson P.D., Poddubnaya L.G., Littlewood D.T.J., Scholz T. 2008: On the position of Archigetes and its bearing on the early evolution of the tapeworms. J. Parasitol. 94: 898-904.

Rego A.A. 1987: Cestóides proteocefalídeos do Brasil. Reorganização taxonômica. Rev. Brasil. Biol. 47: 203-212.

Rego A.A. 1994: Order Proteocephalidea Mola, 1928. In: L.F. Khalil, A. Jones and R.A. Bray (Eds.), Keys to the Cestode Parasites of Vertebrates. CAB International, Wallingford, pp. 257-293.

Rego A.A., Chubb J.C., Pavanelli, G.C. 1999: Cestodes in South American freshwater teleost fishes: keys to genera and brief description of species. Rev. Bras. Zool. 16: 299-367.

Schмidt G.D. 1986: CRC Handbook of Tapeworm Identification. CRC Press, Boca Raton, Florida, USA, 675 pp.

Scholz T., de Chambrier A. 2012: A new genus and species of proteocephalidean tapeworm (Cestoda) from Pangasius larnaudii (Siluriformes: Pangasiidae) in Southeast Asia. J. Parasitol. 98: 648-653.

Scholz T., De Chambrier A., Kuchta R. 2008: Redescription of the tapeworm Monticellia amazonica de Chambrier et Vaucher, 1997 (Cestoda: Proteocephalidea), a parasite of Calophysus

Received 7 January 2013 macropterus (Siluriformes, Pimelodidae) from the Amazon River. Acta Parasitol. 53: 30-35.

Scholz T., de Chambrier A., Mariaux J., Kuchta R. 2011: Redescription of Corallobothrium solidum (Cestoda: Proteocephalidea) and the erection of a new genus, Essexiella, for tapeworms from channel catfishes (Ictaluridae). J. Parasitol. 97: $1142-1151$

Scholz T., De Chambrier A., Salgado-Maldonado G. 2001: Monticellia ophisterni n. sp. (Cestoda: Monticelliidae) from the swamp-eel Ophisternon aenigmaticum (Synbranchiformes) from Mexico. J. Parasitol. 87: 1328-1333.

Twohig M.E., Caira J.N., Fyler C.A. 2008: Two new cestodes of the dwarf whipray, Himantura walga (Batoidea: Dasyatidae), from Borneo, with comments on site and mode of attachment. J. Parasitol. 94: 1118-1127.

Waeschenbach A., Webster B.L., Bray R.A., Littlewood D.T.J. 2007: Added resolution among ordinal level relationships of tapeworms (Platyhelminthes: Cestoda) with complete small and large subunit nuclear ribosomal RNA genes. Mol. Phylogenet. Evol. 45: 311-325.

Waeschenbach A., Webster B.L., Littlewood D.T.J. 2012: Adding resolution to ordinal level relationships of tapeworms (Platyhelminthes: Cestoda) with large fragments of mtDNA. Mol. Phylogenet. Evol. 63: 834-847.

Woodland W.N.F. 1933: On two new cestodes from the Amazon siluroid fish Brachyplatystoma vaillanti Cuv. and Val. Parasitology 25: 485-490.

Woodland W.N.F. 1935: Additional cestodes from the Amazon siluroids pirarará, dorād and sudobīm. Proc. Zool. Soc. London 104: 851-862.

Accepted 24 February 2013 